\title{
Atypical chondroblastic osteosarcoma in the axial skeleton in a dog
}

\section{Osteossarcoma condroblástico atípico no esqueleto axial em cão}

\author{
Francine Maria de França Silva ${ }^{1 *}$; Andrei Kelliton Fabretti; \\ Elisângela Olegário da Silva ${ }^{3}$; Vanessa Carla Lima da Silva ${ }^{4}$; \\ Antônio Carlos Faria dos Reis ; Frederico Celso Lyra Maia ${ }^{6}$; \\ Leucio Câmara Alves ${ }^{6}$; Patrícia Mendes Pereira ${ }^{7}$
}

\begin{abstract}
Osteosarcoma is the most common malignant bone tumor in dogs, most frequently affecting middleto old-aged animals. It is a tumor of mesenchymal origin with great potential for the development of metastases, and is characterized by its aggressive and invasive behavior. In the axial skeleton, primary osteosarcoma is rare but may occur in the ribs, sternum, vertebrae and skull. This paper reports an atypical case of primary chondroblastic osteosarcoma of the rib with esophageal metastasis in a dog. The patient had muffled heart sounds on auscultation, expiratory dyspnea, and severe dehydration. Thoracic radiography showed generalized enlargement of the heart silhouette, suggestive of pericardial effusion. Because of a suspicion of intrathoracic neoplasia and the poor general state of the patient, euthanasia was advised. Necropsy revealed a neoplastic mass within the thoracic cavity, adhered to a rib and the sternum and pericardial sac, in addition to a metastatic mass in the esophagus. Histopathological examination confirmed the diagnosis of this neoplasia. This report describes an unusual case of primary chondroblastic osteosarcoma of the rib in a dog with metastasis in the esophagus. It is considered unusual because of the location of the tumoral mass inside the thoracic cavity and external adhesion to the pericardial sac.
\end{abstract}

Key words: Thoracic cavity, metastasis, malignant tumor, osteoblasts

\section{Resumo}

O Osteossarcoma é o tumor ósseo maligno mais comum nos cães, acometendo com maior frequência animais de média idade a idosos. É um tumor de origem mesenquimal, com grande potencial para o desenvolvimento de metástases, sendo caracterizado pelo seu comportamento agressivo e invasivo. No esqueleto axial, o osteossarcoma primário é considerado raro, pode ocorrer nas costelas, esterno, vértebras e ossos e crânio, além disso, também pode ocorrer no osso pélvico. Este trabalho relata um caso atípico de osteossarcoma condroblástico primário de costela, com metástase esofágica, em um cão. O paciente apresentava abafamento dos sons cardíacos à auscultação, dispneia expiratória e grave desidratação. A radiografia torácica evidenciou o aumento generalizado da silhueta cardíaca, sugestiva

\footnotetext{
${ }^{1}$ Médica Veterinária Autônoma, Recife, PE, Brasil. E-mail: francine_vet@hotmail.com

2 Prof. M.e, Dept ${ }^{\circ}$ de Histologia, Universidade Estadual de Londrina, UEL, Londrina, PR, Brasil. E-mail: fabretti@uel.br

${ }^{3}$ Prof ${ }^{a}$, Universidade do Oeste Paulista, UNOESTE, Presidente Prudente, SP. Discente de Doutorado do Programa de Pós-Graduação em Ciência Animal, UEL, Londrina, PR, Brasil. E-mail: elivet02@gmail.com

4 Médica Veterinária Autônoma, Recife, PE, Brasil. E-mail: vcls2004@yahoo.com.br

${ }_{5}$ Prof. Dr., Dept ${ }^{\circ}$ de Medicina Veterinária Preventiva, UEL, Londrina, PR, Brasil. E-mail: reis@uel.br

${ }^{6}$ Profs. Drs., Dept ${ }^{\circ}$ de Medicina Veterinária, Universidade Federal Rural de Pernambuco, UFRPE, Recife, PE, Brasil. E-mail: fredericomaia3@gmail.com; leucioalves@gmail.com

${ }^{7}$ Prof $^{a}$ Dr $^{\mathrm{a}}$, Dept ${ }^{\circ}$ de Clínicas Veterinárias, Londrina, PR, Brasil. E-mail: pmendes@uel.br

* Author for correspondence
} 
de efusão pericárdica. Devido a suspeita de neoplasia intratorácica e ao estado geral ruim do paciente foi realizada eutanásia e a necropsia revelou a massa neoplásica dentro da cavidade torácica, aderida à costela, ao esterno e ao saco pericárdico, além de uma massa metastática localizada no esôfago. O exame histopatológico confirmou o diagnóstico desta neoplasia. Este relato trata-se de um caso atípico de osteossarcoma condroblástico primário de costela em cão, com metástase no esôfago, sendo considerado atípico devido a localização da massa neoplásica dentro da cavidade torácica, aderida externamente ao saco pericárdio.

Palavras-chave: Cavidade torácica, metástase, neoplasia maligna, osteoblastos

\section{Introduction}

Osteosarcomas represent approximately $80 \%$ $90 \%$ of bone tumors in animals (STEVEN et al., 1992; SELVARAJAH; KIRPENSTEIJN, 2010). They more commonly affect the appendicular skeleton, particularly the metaphysis of long bones, distal portion of the radius and femur, and proximal region of the humerus and tibia (LIPTAK et al., 2008).

In the axial skeleton (ribs, sternum, vertebrae and skull), osteosarcomas are rare and account for approximately $25 \%$ of cases of neoplasia of these bones (STEVEN et al., 1992; DICKERSON et al., 2001). Though less frequent, other primary tumors of the ribs can be diagnosed in dogs, such as chondrosarcoma, hemangiosarcoma, and fibrosarcoma (FEENEY et al., 1982; PIRKEYEHRHART et al., 1995; LIPTAK et al., 2008).

Osteosarcoma of the rib occurs most frequently in young medium- to large-sized dogs, with a mean age of 5.4 years (HEYMAN et al., 1992). Specific location of the tumor in the axial skeleton can influence prognosis, response to treatment, and potential for metastases (HEYMAN et al., 1992; PIRKEY-EHRHART et al., 1995).

The present objective was to report an atypical case of primary chondroblastic osteosarcoma of the rib with esophageal metastasis in a dog.

\section{Case Report}

A 9-year-old male Rottweiler was brought to the Companion Animal Medicine Department of the State University of Londrina with a history of apathy, inappetence, and difficulty moving. The owners reported that at the start of the clinical signs, the dog had received antibiotics for seven days, which improved disposition and appetite. However, several days after the treatment ended, the patient worsened and developed anorexia and dyspnea.

On clinical examination, the patient was in lateral recumbency with severe dehydration, dry mucosae, and significant loss of muscle mass, as well as expiratory dyspnea and scant bilateral serous nasal discharge. On auscultation, there were muffled heart sounds, tachycardia (152 bpm), and tachypnea (56 rpm). Because of the dyspnea, the dog received oxygen during examination and was kept in a calm environment with minimal manipulation to avoid stress. Blood tests showed normocytic normochromic anemia and increased serum concentration of alkaline phosphatase (ALP) $(349 \mu \mathrm{g} / \mathrm{dL})$, and pyuria was observed on urinalysis. Thoracic radiographs were obtained to investigate the presence of intrathoracic, cardiac or pulmonary neoplasia. They showed generalized enlargement of the cardiac silhouette and dorsal displacement of the trachea, suggestive of pericardial effusion (Figure 1A). Thoracic ultrasound revealed a highly vascularized hypoechoic structure, which occupied a large part of the thoracic cavity and had an aspect compatible with neoplasia. Because of the poor condition of the patient and a poor prognosis, euthanasia was agreed upon and a necropsy then performed. 
Figure 1. Primary chondroblastic osteosarcoma of the rib in a dog. A- Lateral radiograph of the thorax showing globoid enlargement of the heart and presence of bone lysis in a sternebra (arrow). B- Macroscopic appearance of the tumoral mass (star) located in the center, and visualization of the lung lobes (arrows). C- Neoplasia adhered (star) to the pericardial sac (arrow); note that the mass did not infiltrate the heart. D- Longitudinal slice of the neoplastic mass showing areas of central necrosis (star) and calcification. E- Longitudinal slice of the metastatic neoplastic mass (star) adhered to the caudal third of the esophagus (arrow). F- Abundant diffuse chondroid matrix produced by neoplastic chondroblasts and calcified osteoid matrix (arrow) H\&E, objective lens: 40x.
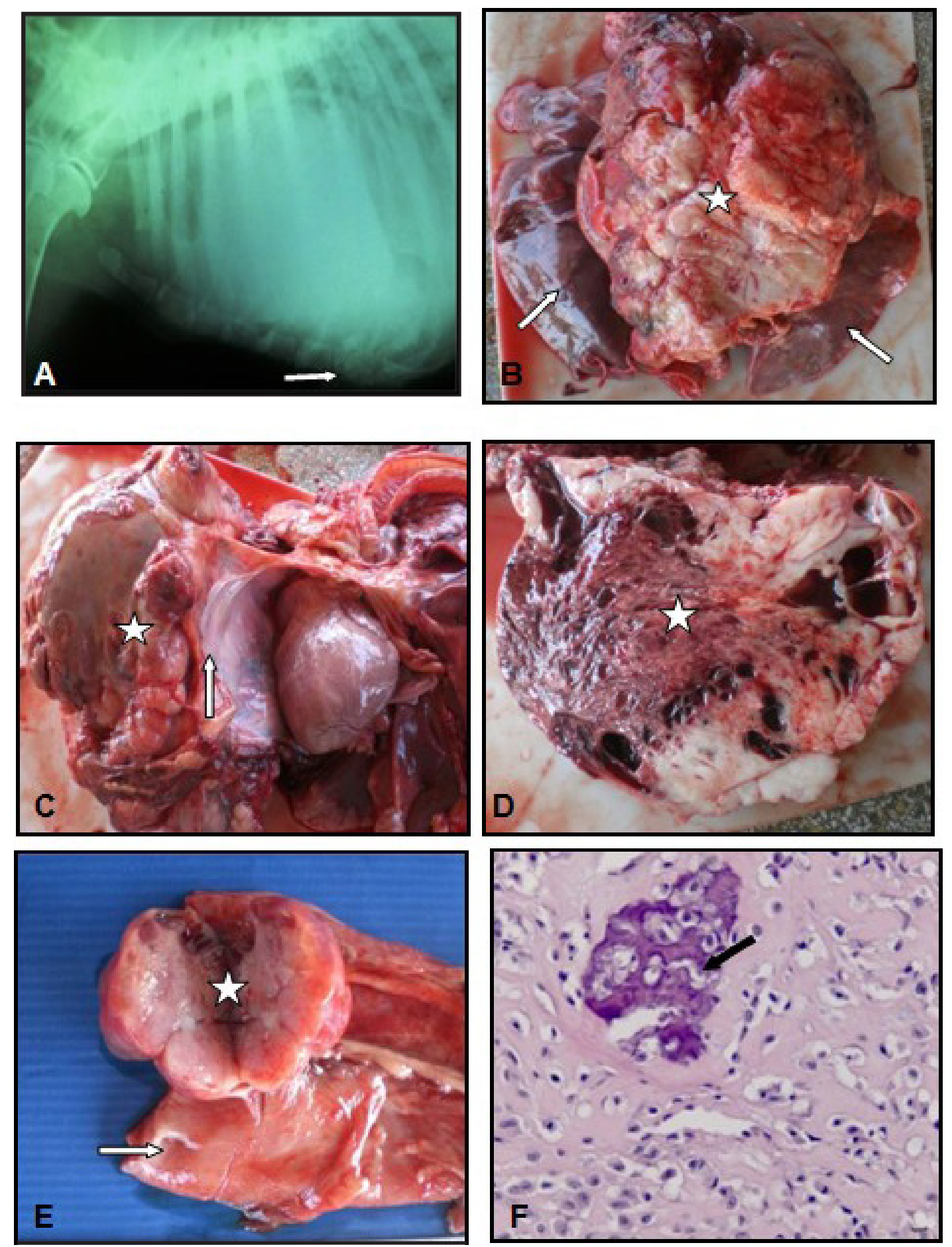

Source: Elaboration of the authors. 
During necropsy, a tissue mass was observed adhered to a rib and the pericardial sac and sternum (Figure 1B and 1C). On macroscopic examination, the mass $(20 \mathrm{~cm})$ was multilobulated, whitish in color, and firm. The whitish color remained after transection of the mass; central reddish areas of friable consistency (Figure 1D) and other areas with a grainy consistency were suggestive of necrosis and calcification, respectively. During necropsy, a tissue mass $(4.5 \mathrm{~cm})$ was also observed adhered to the caudal third of the esophagus (Figure 1E), with characteristics similar to those of the mass adhered to the rib.

Histopathological examination revealed that both masses consisted of proliferation of neoplastic mesenchymal cells arranged in bundles that were interlaced and interspersed with scant to moderate amounts of collagenous matrix. An osteoid matrix and cartilaginous metaplasia were also present. The cells showed moderate to accentuated anisokaryosis, with one or more conspicuous nucleoli and some multinucleated cells. The diagnosis was compatible with primary chondroblastic osteosarcoma of the rib and esophageal metastasis (Figure 1F).

Primary osteosarcoma of the rib, although rare, was diagnosed in the dog in this report, similar to what was reported by Heyman et al. (1992) and Dickerson et al. (2001). According to these authors, primary osteosarcoma of the rib has a low frequency, approximately $10 \%$, when compared with the occurrence of this type of tumor in other bones of the axial skeleton.

The clinical characteristics of the dog in this report regarding size and age were comparable to those cited in the literature for canine patients with osteosarcoma of the rib, that is, large-breed dogs aged 5-9 years (HEYMAN et al., 1992; PIRKEYEHRHART et al., 1995; YUEN, 2000). However, the dog in this report was a male, and females are more predisposed to this type of neoplasia (HEYMAN et al., 1992).

According to Yuen (2000), a presumptive diagnosis of osteosarcoma of the thoracic wall can be made on the basis of clinical history and physical examination and radiographic findings. The main clinical signs seen in the dog in this report were expiratory dyspnea and muffled heart sounds, similar to those observed by Feeney et al. (1982). Another common clinical sign in animals with tumors on the thoracic wall is the presence of a palpable, firm, and variably painful mass over the thorax (FEENEY et al., 1982; PIRKEY-EHRHART et al., 1995). However, this clinical sign was not observed in the patient in this report.

On thoracic radiography, globoid enlargement of the heart silhouette was observed, which is suggestive of pericardial effusion. However, the use of ultrasound examination help rule out pericardial effusion before the necropsy was performed. The necropsy allowed observation of a neoplastic mass arising from a rib and invading the thoracic cavity, which was located entirely within the thoracic cavity, and no pericardial effusion was present. This finding highlights the importance of necropsy as a post mortem diagnostic method, because it allowed macroscopic evaluation of the tumor, as well as collection of samples for microscopic evaluation. Histopathological analysis is the most indicated test for the diagnosis of osteosarcoma (KIRPENSTEIJN et al., 2002; LOUKOPOULOS; ROBINSON, 2007) and allows classification of the tumor based on formation of osteoid matrix into osteoblastic, fibroblastic, chondroblastic, and telangiectasic subtypes (KIRPENSTEIJN et al., 2002; LOUKOPOULOS; ROBINSON, 2007).

Metastases and micrometastases are often observed in the lungs of patients with osteosarcoma; however, in the present patient, these lesions were not observed on thoracic radiographs or macroscopic examination during necropsy. Similar findings were obtained by Yuen (2000). According to Heyman et al. (1992), although the incidence of pulmonary metastasis secondary to osteosarcoma of the axial skeleton may depend on the primary location of the tumor, 
only $10-11 \%$ of patients with osteosarcoma of the axial skeleton have visible metastasis in the lungs at the time of diagnosis.

In the patient described herein, the esophageal mass had macroscopic and microscopic characteristics similar to those of the primary tumor attached to the thoracic wall and thus was considered metastasis. Additionally, Selvarajah and Kirpensteijn (2010) reported that metastases usually have a histologic appearance identical to that of the primary tumor, reinforcing the presence of esophageal metastasis. This is an important finding because the esophagus has not been previously described as a focus of metastasis for this type of neoplasia originating from a rib.

The increased ALP observed in the dog in this report was also described by Yuen (2000), and is justified by the increase of osteoblastic activity in the ribs. However, Mukorera et al. (2011) studied ALP activity in patients with primary esophageal osteosarcoma and found no significant increase. Serum concentration of ALP is associated with prognosis in dogs with osteosarcoma of the rib. Furthermore, regarding prognosis, patients with osteosarcoma of the rib have a risk of death eight times that of other patients (LIPTAK et al., 2008). This information supports the prognosis of the patient as poor, with a high risk of death.

The present report describes a case of primary chondroblastic osteosarcoma of the rib in a dog with metastasis to the esophagus. This presentation was considered atypical because of the location of the neoplasia within the thoracic cavity and external adhesion to the pericardial sac.

\section{Acknowledgments}

The authors are grateful to the Postgraduate Program in Animal Science, State University of Londrina and Postgraduate Program in Animal Bioscience, Rural Federal University of Pernambuco.

\section{References}

DICKERSON, M. E.; PAGE, R. L.; LADUE, T. A.; HAUCK, M. L.; THRALL, D. E.; STEBBINS, M. E.; PRICE, G. S. Retrospective analysis of axial skeleton osteosarcoma in 22 large-breed dogs. Journal of the Veterinary Internal Medicine, Lawrence, v. 15, n. 2, p. 120-124, 2001.

FEENEY, D. A.; JOHNSTON, G. R.; GRINDEM, C. B.; TOOMBS, J. P.; CAYWOOD, D. D.; HANLON, G. F. Malignant neoplasia of canine ribs: clinical, radiographic, and pathologic findings. Journal of the American Veterinary Medical Association, Schaumburg, v. 180, n. 8, p. 927-933, 1982.

HEYMAN, S. J.; DIEFENDERFER, D. L.; GOLDSCHMIDT, M. H.; NEWTON, C. D. Canine axial skeletal osteosarcoma: a retrospective study of 116 cases (1986-1989). Veterinary Surgery, Philadelphia, v. 21, n. 4, p. 304-310, 1992.

KIRPENSTEIJN, J.; KIK, M.; RUTTEMAN, G. R.; TESKE, E. Prognostic significance of a new histologic grading system for canine osteosarcoma. Veterinary Pathology, Washington, v. 39, n. 2, p. 240-246, 2002.

LIPTAK, J. M.; KAMSTOCK, D. A.; DERNELL, W. S.; MONTEITH, G. L.; RIZZO, S. A.; STEPHEN, J.; WITHROW, S. J. Oncologic outcome after curativeintent treatment in 39 dogs with primary chest wall tumors (1992-2005). Veterinary Surgery, Philadelphia, v. 37, n. 5, p. 488-496, 2008.

LOUKOPOULOS, P.; ROBINSON, W. F. Clinicopathological relevance of tumour grading in canine osteosarcoma. Journal of Comparative Pathology, London, v. 136, n. 1, p. 65-73, 2007.

MUKORERA, V.; VAN DER MERWEL, L. L.; LAVY, E.; AROCH, I.; DVIR, E. Serum alkaline phosphatase activity is not a marker for neoplastic transformation of esophageal nodules in canine spirocercosis. Veterinary Clinical Pathology, Santa Barbara, v. 40, n. 3, p. 389392, 2011.

PIRKEY-EHRHART, N.; WITHROW, S. J.; STRAW, R. C.; EHRHART, E. J.; PAGE, R. L.; HOTTINGER, H. L.; HAHN, K. A.; MORRISON, W. B.; ALBRECHT, M. R.; HEDLUND, C. S.; HAMMER, A. S.; HOLMBERG, D. L.; MOORE, A. S.; KING, R. R.; KLAUSNER, J. S. Primary rib tumors in 54 dogs. Journal of the American Animal Hospital Association, Lakewood, v. 31, n. 1, p. 65-69, 1995.

SELVARAJAH, G. T.; KIRPENSTEIJN, J. Prognostic and predictive biomarkers of canine osteossarcoma. The Veterinary Journal, London, n. 185, n. 1, p. 28-35, 2010. 
STEVEN, J. H.; DIEFENDERFER, D. L.; YUEN, L. Primary sarcoma of the ribs in a large, mixed GOLDSCHMIDT, M. H.; NEWTON, C. D. Canine axial breed dog. Canadian Veterinary Journal, Ottawa, v. 41, skeletal osteosarcoma - a retrospective study of 116 cases n. 1, p. $63-65,2000$. (1986 to 1989). Veterinary Surgery, Philadelphia, v. 1, n. 4, p. 304-310, 1992. 